\title{
The Research of Cold Stress on Three Revetment Plants
}

\author{
Yun $\mathrm{He}^{1}$, Yiqiao $\mathrm{Li}^{1} \& \mathrm{Xi} \mathrm{Li}^{2}$ \\ ${ }^{1}$ College of Forestry, Sichuan Agricultural University, Ya'an, Sichuan, China \\ ${ }^{2}$ College of Landscape Architecture, Sichuan Agricultural University, Wenjiang, Sichuan, China \\ Correspondence: Xi Li, College of Landscape Architecture, Sichuan Agricultural University, Wenjiang 611130, \\ Sichuan, China. Tel: 86-8629-0882. E-mail: overseas5588@163.com
}

Received: March 6, 2013 Accepted: April 26, 2013 Online Published: May 15, 2013

doi:10.5539/jas.v5n6p102 URL: http://dx.doi.org/10.5539/jas.v5n6p102

\begin{abstract}
In order to select proper revetment plant to apply in the rock slope protection, we used Cynodon dactylon as control to investigate the effect of cold stress on two wild revetment plants (Pogonatherum paniceum and Eriophorum comosum $)$ in current study. With the dropping of temperature $\left(0^{\circ} \mathrm{C},-5^{\circ} \mathrm{C},-10^{\circ} \mathrm{C},-15^{\circ} \mathrm{C},-20^{\circ} \mathrm{C}\right)$, the content of soluble sugar, soluble protein, and free proline in these three plants rose first, and then decreased. Meanwhile, the chlorophyll content declined, but the electrolyte osmotic rate increased. Under the five different temperatures, the content of soluble sugar and soluble protein were highest $(P<0.05)$ in $E$. comosum, the lowest $(P<0.05)$ in $C$. dactylon, and $P$. paniceum in the middle. The free proline contents in E. comosum was similar to $P$. paniceum at $-15^{\circ} \mathrm{C}$, and $-20^{\circ} \mathrm{C}$, but both of them were significant greater than that in $C$. dactylon $(P<0.05)$. Additionally, $C$. dactylon had the highest electrolyte osmotic rate, and E. comosum was the lowest. Meanwhile, the semilethal low temperature was the lowest $\left(-13.6^{\circ} \mathrm{C}\right)$ in E. comosum as compared to C. dactlylon $\left(-6.86^{\circ} \mathrm{C}\right)$ and $P$. paniceum $\left(-9.37^{\circ} \mathrm{C}\right)$. Both the contents of Chlorophyll $a$ and Chlorophyll $b$ were highest in $P$. paniceum, lowest in C. dactylon, and those in E. comosum were medium. These suggested that $E$. comosum may have the strongest cold resistance capacity, and that in $C$. dactylon was the weakest. The results showed that $E$. comosum was the best option to the rock slope protection due to their strongest anti-cold ability among these three grasses.
\end{abstract}

Keywords: revetment plant, cold stress, cold resistance, osmotic adjustment materials, electrolyte osmotic rate, Chlorophyll, semilethal low temperature

\section{Introduction}

The development in socio-economic cannot achieve without infrastructure development, especially in the construction of road and railway. However, which also brought inevitable destruction on the ecological balance, leading to bareness in surface, decreasing the soil anti-erosion capacity, and aggravating the soil erosion (Wang $\&$ Peng, 1997). Thus, it is very necessary to carry out vegetation restoration in bare rock slope. The key in which is not the slope protection technique and soil matrixes, but the selection of proper revetment plant (Zhen \& Fang, 2009).

However, research in eco-engineering for the rock slope protection is still at the starting stage in China (Xiong et al., 2011). At present, single pasture or lawn grass is selected for rock slope protection, but which is often followed by inadaptability. When the temperature is lower, the water stress occurs, and the survival rate decreases (He et al., 2012). Nevertheless, wild lithophytes can effectively solve this problem due to their advantageous traits (Liu \& Han, 2007). It has been reported that lithophytes can directly grow in steep rock and cemented masonry stone, and they have greater resistance to drought, cold, disease and barren, and fecundity than other grasses. Therefore, the selection of proper lithophytes has important significance in the rock slope protection ( $\mathrm{Li}$ et al., 2004b). According to the survey by Li et al. (2006), Pogonatherum paniceum and Eriophorum comosum can be used as revetment plants because of the characteristics in strong deep roots, and well tolerant to barrenness, drought and water erosion. They can grow in a crack between rocks, and form symbiotic relationships with lower organisms, such as algae, lichen, moss, etc (Li \& Luo, 2006).

At present, systemic researches have been performed in seed certification, drought adaptability, microbial ecological distribution in rhizosphere soil, plant tissue culture, and genetic diversity of Pogonatherum paniceum and Eriophorum comosum (Li et al., 2004a; Wang et al., 2005; Zhuang et al., 2010). However, the study on anti-cold ability of these two grasses has not been reported yet. In the current research, we used Pogonatherum 
paniceum and Eriophorum comosum as experimental materials, and Cynodon dactylon as control to study the cold adaptability of these two plants. Results of this study could provide scientific theoretical basis for selection of revetment plant.

\section{Materials and Methods}

\subsection{Site for Experiment}

The experiment was carried out at the teaching practice base of the college of Forestry, Sichuan Agricultural University, Ya'an, Sichuan province, China. Average altitude, mean annual precipitation, annual temperature and relative air humidity in this area is $620 \mathrm{~m}, 1800 \mathrm{~mm}, 16.2{ }^{\circ} \mathrm{C}$, and $79 \%$, respectively. The annual cumulative temperature $\left(\geq 10^{\circ} \mathrm{C}\right)$ is $5231^{\circ} \mathrm{C}$, annual sunshine is $1039.6 \mathrm{~h}$, and frost-free period is $298 \mathrm{~d}$.

\subsection{Experimental Design}

Wild Pogonatherum paniceum, Eriophorum comosum and Cynodon dactylon were collected from the rock slope at the town of Duoying, Ya'an, and the slope gradient was steeper than $85 \%$. Pot experiment was used in this study. The experimental soil was purple sandy shale soil, and which was the heavy clay soil with a $\mathrm{pH}$ value of 6.2 .

The collected seedlings were planted on $10^{\text {th }}$ May 2012. Six seedlings were planted in each pot with 20 duplicates in each grass. Fresh leaves were collected from three grasses at 7 am on $15^{\text {th }}$ November 2012 . The collected leaves were stored in ice bags, and taken back to the lab rapidly. Leaves were cleaned with deionized water, and dried by the filter paper. Then, five different temperatures include $0^{\circ} \mathrm{C},-5^{\circ} \mathrm{C},-10^{\circ} \mathrm{C},-15^{\circ} \mathrm{C}$, and $-20^{\circ} \mathrm{C}$ were employed to treat leaves, and 10 duplicates in each temperature treatment.

\subsection{Indexes Measuring}

The membrane permeability was measured by conductimeter (DDS-11A). The soluble protein content was tested with staining of coomassie brilliant blue R 250, and followed the described by Zhang (Zhang, 2006). The soluble sugar content was measured by sulfuric anthrone reaction based on the method of $\mathrm{Li}(\mathrm{Li}, 2000)$. The Chlorophyll content was determined according to Wintermans and De Motes (Wintermans \& De Mots, 1965). The free proline was measured directly using the ninhydrin colorimetric method of Troll and Lindsley (Troll \& Lindsley, 1955)

\subsection{Statistical Analysis}

One-way ANOVA was used to compare the effect of treatments and, Tukey's test was used for the multiple comparison. Statistics analysis was performed using SPSS 17.0 software, and the P-value for significance was set at $P<0.05$.

\section{Results}

\subsection{Effect of Low Temperature Stress on Membrane Permeability of Leaf Cells}

As shown in the Figure 1, the electrolyte osmotic rate of three grasses went up with the decrease of temperature. The electrolyte osmotic rate of C. dactlylon increased quickly from 0 to $-15^{\circ} \mathrm{C}$, and slower growth was found after $-15^{\circ} \mathrm{C}$. However, the rising trend was slowly before $-10^{\circ} \mathrm{C}$ and then increased sharply in E. comosum and $P$. paniceum. Additionally, the electrolyte osmotic rate was lowest in E. comosum, greatest in C. dactlylon, and $P$. paniceum was medium at all temperatures.

The semilethal low temperatures of three plants were calculated based on the fitted regression equation of the electrolyte osmotic rate (Table 1). The semilethal low temperature was lowest in E. comosum $\left(-13.6^{\circ} \mathrm{C}\right)$, highest in C. dactlylon $\left(-6.86^{\circ} \mathrm{C}\right)$, and that in $P$. paniceum $\left(-9.37^{\circ} \mathrm{C}\right)$ in the middle, which were consistent with the electrolyte osmotic rate of three plants.

Table 1. The semilethal temperature of three plants

\begin{tabular}{llll}
\hline Grass & Logistic equation & $\mathrm{LT}_{50}{ }^{\circ} \mathrm{C}$ & $\mathrm{R}_{2}$ \\
\hline E. comosum & $\mathrm{Y}=67.513 /\left(1+\mathrm{e}^{2.461-0.198 x}\right)$ & -13.6 & 0.9965 \\
P. paniceum & $\mathrm{Y}=92.765 /\left(1+\mathrm{e}^{1.482-0.154 x}\right)$ & -9.37 & 0.9876 \\
C. dactlylon & $\mathrm{Y}=80.516 /\left(1+\mathrm{e}^{1.978-0.366 x}\right)$ & -6.86 & 0.9915 \\
\hline
\end{tabular}




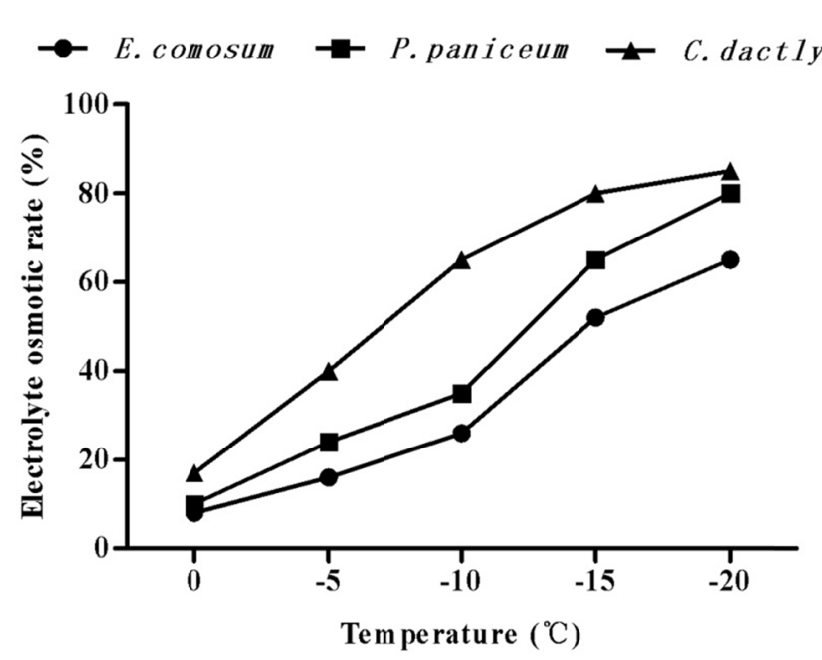

Figure 1. Variation of electrolyte osmotic rate in leaf of three plants under low temperature stress

\subsection{Effect of Low Temperature Stress on Osmotic Adjustment Materials of Leaf}

In our study, the variation trends of soluble sugar were similar in the three plants (Figure 2). The soluble sugar content increased from 0 to $-15^{\circ} \mathrm{C}$ and then decreased, and the decline in $C$. dactlylon was the fastest. In addition, E. comosum had the highest soluble sugar content $(P<0.05)$ at the five temperatures, and those in $C$. dactlylon were lowest $(P<0.05)$ in all points.

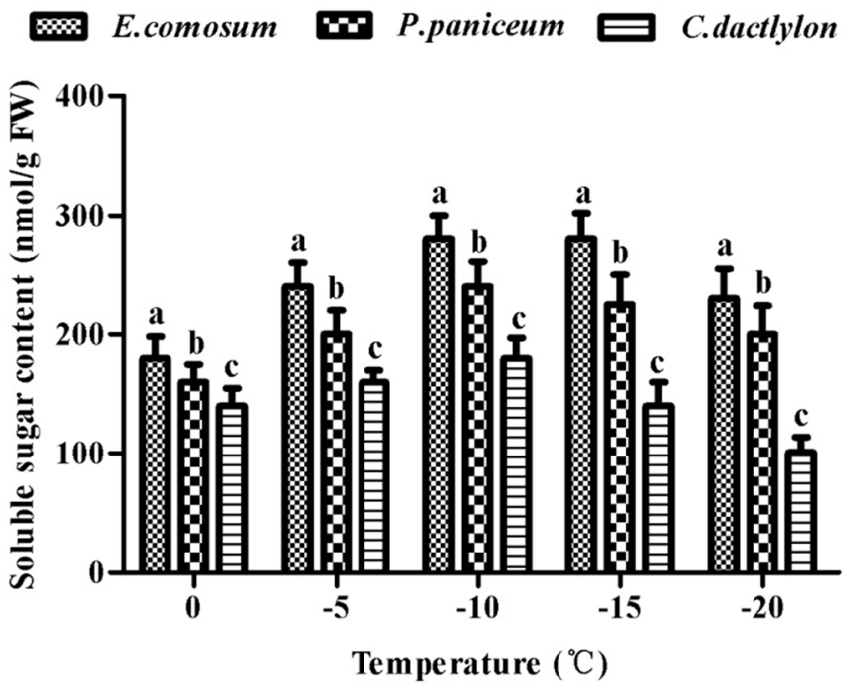

Figure 2. Variation of soluble sugar content in leaf of three plants under low temperature stress

Different lowercase above the columns indicate significant differences $(P<0.05)$.

The soluble protein content in C. dactlylon and P. paniceum rose from 0 to $-10^{\circ} \mathrm{C}$, and followed by slow declines (Figure 3). However, the soluble protein content in E. comosum slowed down rapidly after reaching the peck at $-15^{\circ} \mathrm{C}$. It was also can be seen in the Figure 3, C. dactlylon had the lowest $(P<0.05)$ soluble protein content under the different temperatures, the highest was found in E. comosum $(P<0.05)$. 


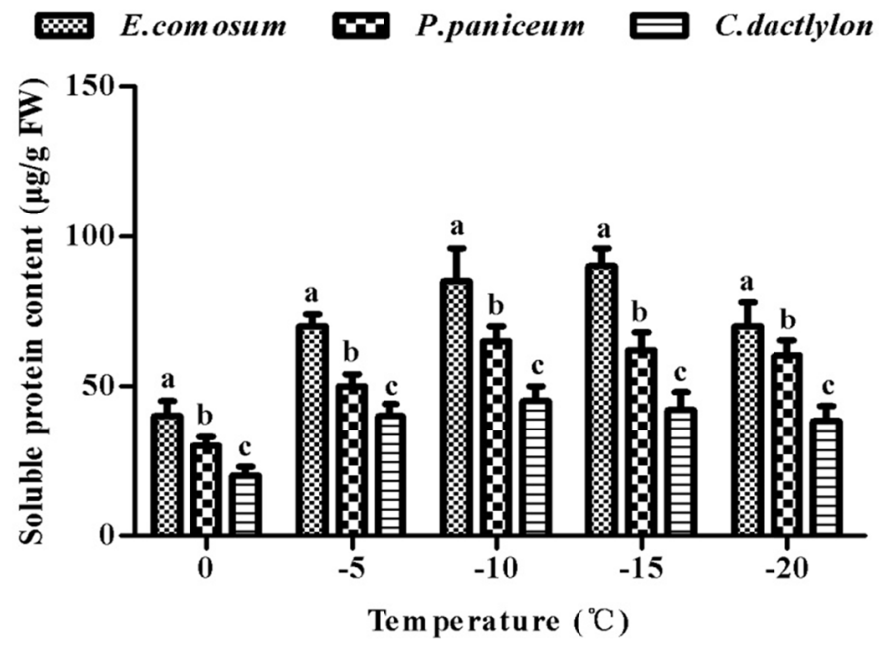

Figure 3. Variation of soluble protein content in leaf of three plants under low temperature stress

Different lowercase above the columns indicate significant differences $(P<0.05)$.

It can be seen from Figure 4 that the change trends in three plants were different. Specifically, the free proline content in E. comosum went up from 0 to $-10^{\circ} \mathrm{C}$, and declined sharply from $-10^{\circ} \mathrm{C}$ to $-15^{\circ} \mathrm{C}$, then decreased gradually. The free proline content in P. paniceum increased slowly as the temperature decrease, and got to the top at $-15^{\circ} \mathrm{C}$, then slowed down gradually. However, the free proline content in C. dactlylon rose from 0 to $-5^{\circ} \mathrm{C}$, and followed by a decrease trend. Meanwhile, the free proline content of E. comosum was highest at all temperatures $(P<0.05)$, and lowest in $C$. dactlylon $(P<0.05)$ under the temperatures of $0^{\circ} \mathrm{C},-5^{\circ} \mathrm{C}$ and $-10^{\circ} \mathrm{C}$. But the free proline content in E. comosum was similar to that in $P$. paniceum, and significant than that in $C$. dactlylon $(P<0.05)$ under the temperature of $-15^{\circ} \mathrm{C}$ and $-20^{\circ} \mathrm{C}$.

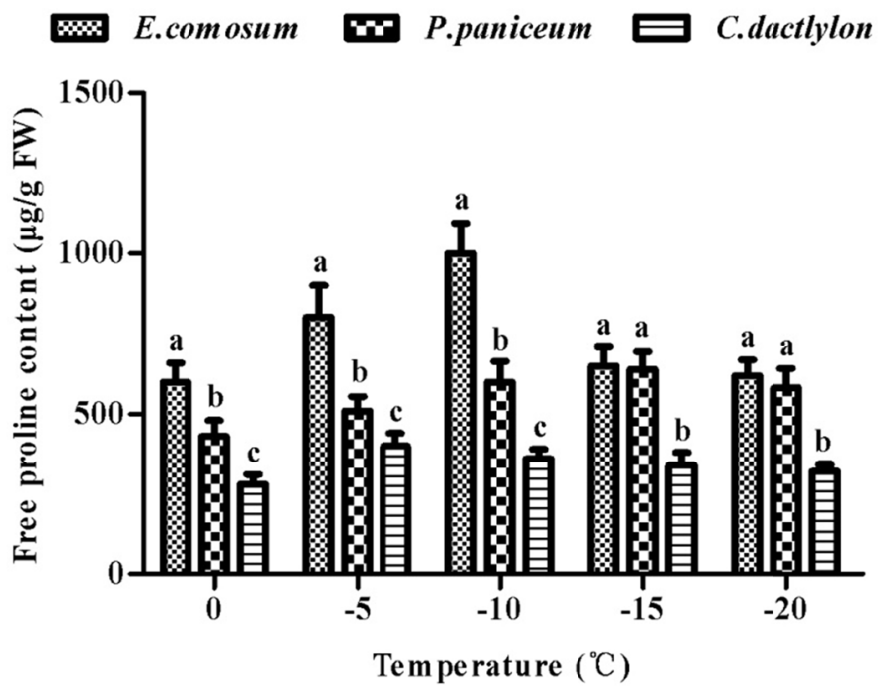

Figure 4. Variation of free proline content in leaf of three plants under low temperature stress

Different lowercase above the columns indicate significant differences $(P<0.05)$.

\subsection{Effect of Low Temperature Stress on Chlorophyll Content of Leaf}

The effect of low temperature stress on chlorophyll $a$ and chlorophyll $b$ content of leaf was shown in Figure 5(A) and 5(B), respectively. The content of chlorophyll $a$ and chlorophyll $b$ in three plants descended with decreasing disposed temperature. The decrease trend of chlorophyll $a$ content was slower that of chlorophyll $b$. Both 
chlorophyll $a$ and chlorophyll $b$ were lowest in $C$. dactlylon among experimental grasses at five treated temperatures, the highest chlorophyll a content was found in P. paniceum, and that in E. comosum was medium.

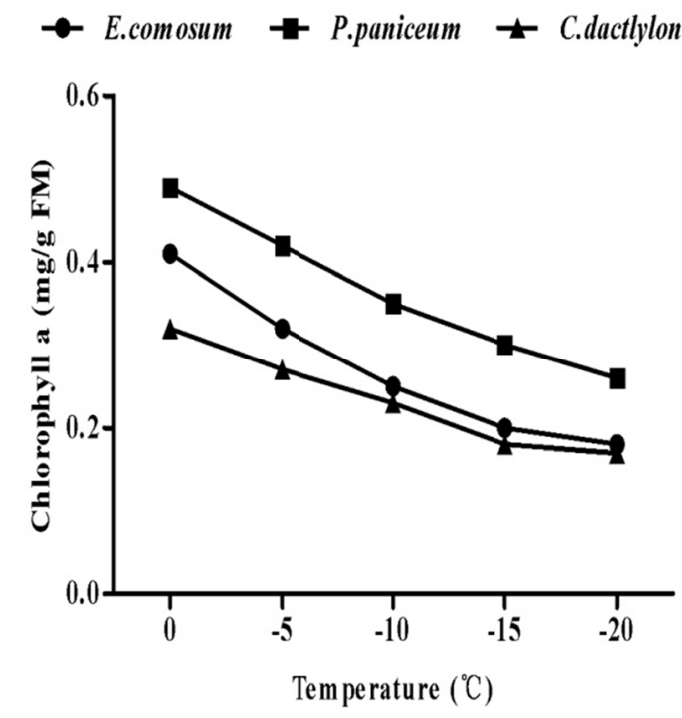

(A)

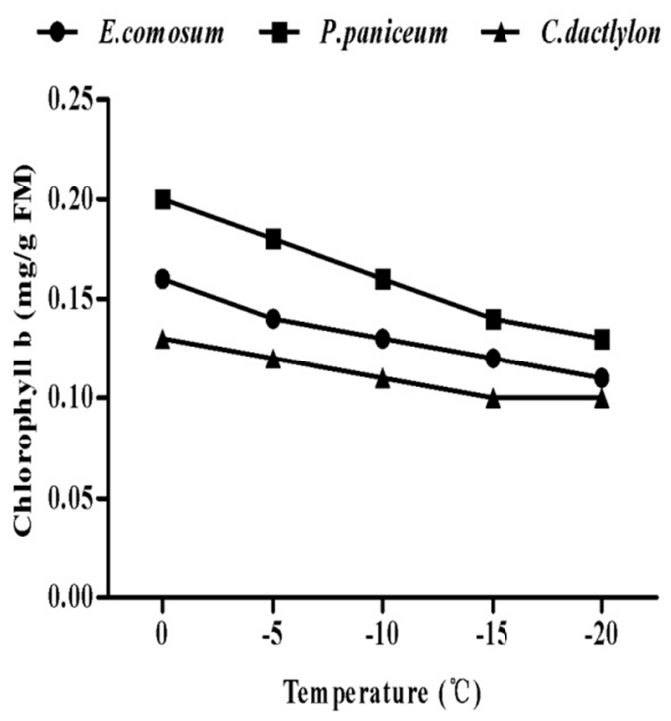

(B)

Figure 5. Variation of chlorophyll content in leaf of three plants under low temperature stress

\section{Discussion}

In general condition, the production and cleanup of free radical exists in dynamic equilibrium in plants. When the plant is under the environment stress, the balance of free radical will be destroyed. In this case, the accumulation of free radical can cause harm to cells, and the plasmalemma system will be the first by this impact (Iriti \& Faoro, 2009). Under the low temperature stress, both the structure and functions of plasmalemma are damaged, which cause the increase in cell membrane permeation and electrical conductivity, and can reflect the damaged condition of plant (Wang et al., 2011). The electrical conductivity in plant with strong anti-cold ability is lower than that in plant with weak cold-resistance at the same temperature (Sun et al., 2009). Chen et al (1999) demonstrated that plant will suffer irreversible damage when a wide-range increase is occurred in the electrical conductivity between two temperatures (Chen, 1999). In our study, the electrolyte osmotic rate of three grasses went up with the temperature decreasing. This showed that the damage degree of cell membrane rose as temperature dropped. In addition, both the electrolyte osmotic rate at temperatures and the semilethal low temperature were lowest in E. comosum. This illustrated that E. comosum have strongest anti-cold ability among these three plants. Tian et al. (2011) investigated the effects of chilling stress on relative electric conductivity in different cultivars of Anthunium andraenum. Their results concluded that the relative electric conductivity was lowest in Alabamb which had the strongest chilling resistance (Tian et al., 2011).

The content of soluble sugar, soluble protein and free proline are most important osmotic adjustment materials (Babu et al., 1999). As an osmoregulatory factor, the soluble sugar can regulate osmotic potential, and assist in enhancing stress resistance (Irigoyen et al., 2006). The accumulation of soluble sugar can improve the osmotic pressure and water-retaining capacity of plant, thus boosting the cold resistance (Ma et al., 2010). The soluble protein has stronger hydrophilia, and can improve the water-possessing ability and protoplasm elasticity in cell as well. Thus, the increase of soluble protein can also strengthen the stress resistance (Zhu et al., 2011). In this experiment, both the soluble sugar and soluble protein content were highest in E. comosum, and lowest in $C$. dactlylon at all temperatures. These also suggested that the cold resistance in E. comosum were highest among the three grasses. Moreover, the soluble sugar and soluble protein content went up from 0 to $-15^{\circ} \mathrm{C}$ in all measured grasses. These may be explained that plants accumulated soluble sugar and soluble protein to fight with cold stress from 0 to $-15^{\circ} \mathrm{C}$. But as temperature continued to drop, cells need them to maintain the energy supply, or cells suffered irreversible damage, thus they decreased after $-15^{\circ} \mathrm{C}$. Xu et al. (2011) studied the changes of osmotic regulatory metabolites in eight bamboo species under low temperature stress. The results showed the contents of soluble protein and soluble sugar changed significantly under low temperature, and which form the cold-resistance varieties were higher than that of the others (Xu \& Dai, 2011). 
It has been demonstrated that the free proline content is closely related with cold resistance in plant, the accumulation of which is considered an adaptation to the cold stress (Dörffling et al., 2008). The increase of proline can decrease the water potential and raise the water-retaining capacity under the low temperature. Thus, its accumulation can as a measure of anti-cold ability (Ashraf \& Foolad, 2007). In this study, there were varying degrees of growth with decreasing temperature found in the free proline of three grasses. Meanwhile, the free proline content of E. comosum was highest at all temperatures. These results indicated that these three grasses can improve anti-cold ability through accumulating the proline content, and the anti-cold ability was best in $E$. comosum. The study of Li et al. (2011) also found that free proline content of different Medicago sativa species showed upward trends under low temperature stress (Li, 2011).

The central role of chlorophyll in photosynthesis is to harvest light energy, and converse it to chemical energy. The chlorophyll content direct affects the photosynthesis capability (Mauzerall, 1976). Chlorophyll $a$ alone exists in the core complex of photosystem. Its organization and composition have highly conservation. Chlorophyll $b$ is an ubiquitous accessory pigment, whose biosynthesis plays a key role in the adaptation to various light environments (Tanaka et al., 1998). In current study, as the temperature dropping, both Chlorophyll $a$ and Chlorophyll $b$ contents in measured plants decreased. It meant that photosynthesis in all of the three plants was expected to be negatively affected by these changes. Under the different temperatures, $C$. dactlylon had the lowest contents of Chlorophyll $a$ and Chlorophyll $b$ suggested that the photosynthesis of $C$. dactlylon was the weakest among these three grasses.

\section{Conclusion}

In conclusion, plants can adapt to low temperature through adjusting the content of osmotic adjustment materials. E. comosum had the highest content of soluble sugar, soluble protein and free proline, higher Chlorophyll contents among three plants, and lowest electrolyte osmotic rate. Additionally, the semilethal low temperature in E. comosum was also the lowest. From the results of the present experiment, it was concluded that cold resistance of these three revetment plants was decreased in the order of E. comosum, P. paniceum, and in C. dactlylon.

\section{Acknowledgements}

This study was supported by Science Fund of Sichuan Province (No. 12ZA116).

\section{References}

Ashraf, M., \& Foolad, M. (2007). Roles of glycine betaine and proline in improving plant abiotic stress resistance. Environmental and Experimental Botany, 206-216. http://dx.doi.org/10.1016/j.envexpbot.2005.12.006

Babu, R. C., Pathan, M. S., Blum, A., \& Nguyen, H. T. (1999). Comparison of measurement methods of osmotic $\begin{array}{lllll}\text { adjustment in rice cultivars. Crop Science, } & 39(1), & 150-158 .\end{array}$ http://dx.doi.org/10.2135/cropsci1999.0011183X003900010024x

Chen, J. B. (1999). The application of conductometry in plant cold resistance. Journal of Yunnan Tropical Crops Science and Technology, 22(1), 26-28 (In Chinese).

Dörffling, K., Schulenburg, S., Lesselich, G., \& Dörffling, H. (2008). Abscisic acid and proline levels in cold hardened winter wheat leaves in relation to variety - specific differences in freezing resistance. Journal of Agronomy and Crop Science, 165(4), 230-239. http://dx.doi.org/10.1111/j.1439-037X.1990.tb00857.x

He, Y., Li, X. W., \& Gong, W. (2012). Response of membrane permeability and soluble carbonydrate of three native petrophile plants to low temperatures stress. Journal of Sichuan Agricutural Univerisity, 30(1), 42-45. http://dx.doi.org/10.3969/j.issn.1000-2650.2012.01.008

Irigoyen, J., Einerich, D., \& Sánchez-Díaz, M. (2006). Water stress induced changes in concentrations of proline and total soluble sugars in nodulated alfalfa (Medicago sativd) plants. Physiologia Plantarum, 84(1), 55-60. http://dx.doi.org/10.1034/j.1399-3054.1992.840109.x

Iriti, M., \& Faoro, F. (2009). Chemical diversity and defence metabolism: how plants cope with pathogens and ozone pollution. International journal of molecular sciences, 10(8), 3371-3399. http://dx.doi.org/10.3390/ijms10083371

Li, H. S. (2000). The Experiment Principle and Technology of Plant Physiology. Beijing: Higher Education Press (In Chinese). 
Li, T., Li, J. P., \& Zhao, Z. W. (2004a). Arbuscular mycorrhizas in a valley-type savanna in southwest China. Mycorrhiza, 14(5), 323-327. http://dx.doi.org/10.1016/j.apsoil.2009.09.006

Li, X., \& Luo, C. D. (2006). Study on Seed Certification and Seeding Quantity about Two Petrophile Plants. Pruataculture and Animal Husbandry, 8, 5-7. http://dx.doi.org/10.3969/j.issn.1673-8403.2006.08.002

Li, X., Luo, C. D., \& Chen, Q. B. (2004b). Preliminary study of plant selection about vegetation of rock slope. Chinese Landscape Architecture, 20(9), 52-53 (In Chinese). http://dx.doi.org/10.3969/j.issn.1000-6664.2004.09.013

Li, X. A. (2011). Effects of chilling stress on proline and soluble sugar content of Melilotus ruthenicus and He-tian alfalfa. Journal of Qinghai University (Nature Science), 29(4), 10-13 (In Chinese).

Liu, C. X., \& Han, L. B. (2007). Review of researches in vegetation restoration of freewat slopes. Acta ecologica sinica, 27(5), 2090-2098 (In Chinese).

Ma, Y. Y., Zhang, Y. L., Lu, J., \& Shao, H. B. (2010). Roles of plant soluble sugars and their responses to plant cold stress. African Journal of Biotechnology, 8(10), 2004-2010.

Mauzerall, D. (1976). Chlorophyll and photosynthesis. Philosophical Transactions of the Royal Society of London. B, Biological Sciences, 273(924), 287-294. http://dx.doi.org/10.1111/j.1751-1097.1978.tb07737.x

Sun, C., Cao, H., Chen, S., Feng, M., Li, R., \& Ma, Z. (2009). Study on Cold Resistance of Snake Fruit by Application of Electrical Conductivity and Logistic Equation. Acta Agriculturae Jiangxi, 4, 9-15 (In Chinese).

Tanaka, A., Ito, H., Tanaka, R., Tanaka, N. K., Yoshida, K., \& Okada, K. (1998). Chlorophyll a oxygenase (CAO) is involved in chlorophyll b formation from chlorophyll a. Proceedings of the National Academy of Sciences, 95(21), 12719-12723. http://dx.doi.org/10.1073/pnas.95.21.12719

Tian, D. Q., Ge, Y. Y., Pan, G. M., Shen, X. L., He, Y., Zhang, Z., Liu, X. J., \& Zhu, Z. J. (2011). Morphological and physiological characteristics of different cultivars of Anthurium andraenum under chilling stress. Acta Hortricultural Sinica, 38(6), 1173-1179 (In Chinese).

Troll, W., \& Lindsley, J. (1955). A photometric method for the determination of proline. Journal of biological chemistry, 215, 655-660.

Wang, B. S., \& Peng, S. L. (1997). Plant Ecology. Beijing: China Environmental Science Press (In Chinese).

Wang, H., Peng, L., Li, S., \& Bai, B. (2005). Growth characteristics of rock plant Pogonatherum paniceum. The Journal of Applied Ecology, 16(8), 1432-1436 (In Chinese).

Wang, Y., Zhou, M., Gong, X., Liu, C., Hong, M., Wang, L., \& Hong, F. (2011). Influence of Lanthanides on the Antioxidative Defense System in Maize Seedlings Under Cold Stress. Biological trace element research, 142(3), 819-830. http://dx.doi.org/10.1007/s12011-010-8814-y

Wintermans, J., \& De Mots, A. (1965). Spectrophotometric characteristics of chlorophylls $a$ and $b$ and their phenophytins in ethanol. Biochimica et Biophysica Acta (BBA)-Biophysics including Photosynthesis, 109(2), 448-453. http://dx.doi.org/10.1016/0926-6585(65)90170-6

Xiong, L., Chen, K. S., \& Yin, Y. (2011). Investigation and Analysis of Slope Protection for Guizhou Province Expressways. Construction Technology, 15, 17-20 (In Chinese).

Xu, C. B., \& Dai, Q. M. (2011). Changes of three osmotic regulatory metabolites contents in leaves of bamboo under low temperature stress. Journal of Henan Agricultural Sciences, 40(1), 127-130 (In Chinese).

Zhang, J. E. (2006). The Methods and Technologies of Common Experiment in Ecology. Beijing: Chemical Industry Press (In Chinese).

Zhen, Y. L., \& Fang, X. D. (2009). Application of Vegetation Slope Protection Technique in Rock Slope of Water Transport Tunnel in Yanshan Reservoir. Water Resources and Power, 6, 49-51 (In Chinese).

Zhu, Z., Jiang, J., Jiang, C., \& Li, W. (2011). Effects of low temperature stress on SOD activity, soluble protein content and soluble sugar content in Camellia sinensis leaves. Journal of Anhui Agricultural University, 1, 6-11 (In Chinese).

Zhuang, G. Q., Ma, D. W., Wang, W. G., Wang, S. H., \& Chen, F. (2010). Genetic diversity of Pogonatherum paniceum (Lam.) Hack. in Southwest China revealed by AFLP markers. African Journal of Biotechnology, $8(7), 1226-1232$. 